\title{
Molecular mechanisms contributing to glucocorticoid resistance in lymphoid malignancies
}

\author{
Blanca Scheijen \\ Department of Pathology, Radboud University Medical Center and Radboud Institute for Molecular Life Sciences, GA 6525, \\ Nijmegen, the Netherlands. \\ Correspondence to: Dr. Blanca Scheijen, Department of Pathology, Radboud University Medical Center and Radboud Institute for \\ Molecular Life Sciences, Geert Grooteplein Zuid 10, GA 6525, Nijmegen, the Netherlands. E-mail: blanca.scheijen@radboudumc.nl \\ How to cite this article: Scheijen B. Molecular mechanisms contributing to glucocorticoid resistance in lymphoid malignancies. \\ Cancer Drug Resist2019;2:647-64. http://dx.doi.org/10.20517/cdr.2019.29
}

Received: 14 Apr 2019 First Decision: 13 Jun 2019 Revised: 24 Jun 2019 Accepted: 22 Aug 2019 Published: 19 Sep 2019

Science Editor: Helen M. Coley Copy Editor: Cai-Hong Wang Production Editor: Jing Yu

\begin{abstract}
Despite the introduction of many novel therapies into the clinic to target hematological malignancies, glucocorticoids (GCs) still remain one of the cornerstone drugs in first-line treatment of lymphoid tumors. However, a significant portion of the patients display acquired GC therapy resistance. This review will describe the different molecular mechanisms that contribute to $G C$ resistance in lymphoid tumors. These include suppression of glucocorticoid receptor (GR) expression, activation of cell signaling pathways that modulate GR function, differential recruitment of transcriptional co-regulators, and changes in chromatin accessibility. Many of these mechanisms are interconnected to genetic alterations associated with relapsed disease in lymphoid malignancies.
\end{abstract}

Keywords: Glucocorticoid receptor, therapy resistance, acute lymphoblastic leukemia, non-Hodgkin lymphoma, multiple myeloma

\section{INTRODUCTION}

Glucocorticoids (GCs) are primary stress hormones that maintain homeostasis and control a broad range of physiological processes, including immune system function, skeletal growth, reproduction, metabolism, energy production and central nervous system function ${ }^{[1]}$. Based on their strong anti-inflammatory and immune-suppressive actions, synthetic GCs are widely used for the treatment of inflammatory conditions, such as organ transplant rejection, autoimmune diseases and asthma, as well as anticancer therapy for

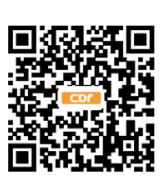


lymphoid malignancies ${ }^{[2]}$. Because of their hydrophobic nature, GCs readily diffuse from the circulation into tissues and cells, where they orchestrate various cellular responses, including cell proliferation, differentiation and apoptosis in a tissue-, cell type- and developmental stage-specific manner. Both endogenous and synthetic GCs exert their action by binding and activating the glucocorticoid receptor (GR) encoded by the $\mathrm{NR}_{3} \mathrm{C}_{1}$ gene, which is a member of the nuclear receptor superfamily of liganddependent transcription factors ${ }^{[3]}$. Consistent with the pleiotropic effects of GCs, GR is ubiquitously expressed and necessary for life after birth ${ }^{[4]}$.

Extensive research on the mechanism of action of GCs and GR protein function in mediating sensitivity and specificity of the different biological responses, has made an important contribution in unraveling the complexity of GC signaling and its regulation. Especially, studies directed towards the identification of molecular pathways underlying GC resistance in hematological cancers have yielded valuable information for novel therapeutic approaches to target this clinical problem. This review will focus on the therapeutic effects of synthetic GCs in the treatment of hematological malignancies of lymphoid origin, and mechanisms of acquired resistance to GCs.

\section{THERAPEUTIC EFFECTS OF GCS IN LYMPHOID MALIGNANCIES}

The main effects of GCs in lymphoid tissue are growth arrest and induction of programmed cell death. After the initial observation in 1944 that hydroxyl-corticosterone induced apoptosis in malignant mouse lymphocytes, synthetic GCs were implemented in the clinical treatment of lymphomas and leukemia ${ }^{[5]}$. Nowadays, prednisone and dexamethasone still are central drugs in the main therapy of most lymphoid malignancies, both for pediatric and adult patients ${ }^{[6]}$. The cytotoxic effects of GCs have been successful exploited in the cancer therapy of acute lymphoblastic leukemia (ALL), but resistance to GCs in vitro and in vivo has been imminently recognized as an adverse prognostic factor in ALL ${ }^{[7]}$. ALL is characterized by an accumulation of early immature lymphocytes within the bone marrow compartment and is largely a childhood cancer. B-cell precursor ALL (BCP-ALL) is the predominant subtype (85\%), and corticosteroids in conjunction with other chemotherapeutic drugs, such as vincristine, anthracyclines, antimetabolites and asparaginase, together with improved risk stratification have resulted in cure rates exceeding $90 \%$ in children $^{[8]}$. In childhood ALL, the prednisone response after 7-day of monotherapy is a prognostic factor utilized in the adaptation of chemotherapy protocols ${ }^{[9-11]}$. In adult ALL, treatments have been adapted from the successful childhood ALL therapy regimens, but response rates are unfortunately less favorable with only $40 \%$ disease-free survival after 5 years ${ }^{[12]}$. In part, this is due to the fact that adults tolerate less the intensive chemotherapy regimens, which require adaptation of treatment schedules, and the occurrence of a larger proportion of high-risk ALL subtypes in adult BCP-ALL, such as BCR-ABL1-positive ALL. Highrisk patients and refractory/relapsed disease will often undergo allogeneic stem cell transplantation (SCT). Novel targeted therapeutic modalities involving tyrosine kinase inhibitors and CD19 chimeric antigen receptor (CAR) T-cell immunotherapy seem to yield more promising results in adult ALL treatment ${ }^{[13]}$.

Chronic lymphocytic leukemia (CLL) is a disease of mature B cells that accumulate over time in the blood stream, lymph nodes and bone marrow. Several studies performed in the 1980s and 1990s showed no additional benefit of corticosteroids to other (mono) therapies and reported severe toxicity, such as myelosuppression and serious infections ${ }^{[14]}$. Therefore, the standard of first-line treatment in CLL consists of immuno-chemotherapy, often fludarabine, cyclophosphamide and anti-CD20 antibody rituximab (FCR), without synthetic GCs. However, high-dose methylprednisolone (HDMP) has been shown to induce apoptosis in cultured CLL cells from patients with relapsed or resistant disease ${ }^{[15]}$, and significant response rates have been observed for HDMP together with rituximab in refractory/relapsed CLL patients ${ }^{[16-19]}$. HDMP has been shown to suppress Wnt signaling in CLL by down-regulating LEF-1 protein expression ${ }^{[20]^{\circ}}$, which acts as a survival factor in $\mathrm{CLL}^{[21]}$. Thus, HDMP in conjunction with conventional immuno (-chemo) therapy is one of the options to be considered for high-risk CLL treatment. 
Hodgkin lymphoma (HL) shows a bimodal age distribution (15-35 years of age and after 55 years of age), and can be divided in two categories, classic HL (cHL) and the rare entity of nodular lymphocytepredominant $\mathrm{HL}^{[22]}$. $\mathrm{cHL}$ is characterized by the presence of $\mathrm{CD} 30$-positive multinucleated B-lymphocytes, termed Hodgkin Reed-Sternberg cells, which orderly spread as malignant lymphocytes throughout the lymphatic system. The HRS cells account only for $1 \%-10 \%$ of the tumor tissue in a background of reactive immune cells, creating a highly abundant inflammatory tumor microenvironment ${ }^{[22]}$. Current first-line regimen for patients with HL is mostly ABVD (adriamycin, bleomycin, vinblastine and dacarbazine), sometimes in combination with radiotherapy, which achieves a 5-year progression-free survival of about $80 \%$ for advanced stage disease ${ }^{[23]}$. Another protocol, called escalated BEACOPP (bleomycin, etoposide, adriamycin, cyclophosphamide, vincristine, procarbazine and prednisone), shows in some studies a better progression-free survival, but also more side effects (higher mortality rate, secondary malignancies and sterility risk $)^{[23]}$. However, the additive beneficial effects of corticosteroids in HL treatment regimens have not been specifically addressed in (pre) clinical studies. Novel strategies with less toxicity-related side effects that show promising results for cHL treatment are brentuximab vedotin, a CD30-dircted antibody conjugate, and anti-PD1 antibodies nivolumab and pembroluzimab ${ }^{[24]}$.

Non-Hodgkin lymphoma (NHL) is the most frequent hematological cancer in adults and represents a broad collection of more than 30 different subtypes of lymphoid malignancies, both of mature B-cell and T-cell/Natural Killer-cell origin ${ }^{[25]}$. Common types include diffuse large B cell lymphoma (DLBCL), follicular lymphoma, mantle cell lymphoma (MCL) and the more indolent group of marginal zone lymphomas. Despite this heterogeneity, most NHL with progressive disease are treated with relatively similar treatment protocols, which consist of immuno-chemotherapy that includes synthetic GCs ${ }^{[25]}$. This typically involves rituximab in combination with $\mathrm{CHOP}$ (cyclophosphamide, doxorubicin, vincristine and prednisone). Other approaches for low to intermediate risk DLBCL comprise of alternative anthracyclinebased combinations (R-ACVBP $)^{[26]}$, and for aggressive DLBCL dose-adjusted administration of cytotoxic agents (DA-EPOCH-R), which yields a durable remission in patients with MYC-rearranged B-cell lymphoma ${ }^{[27]}$. For indolent NHL and MCL, the combination of bendamustine plus rituximab has shown improved long-term disease control compared to $\mathrm{R}_{-} \mathrm{CHOP}^{[28]}$. Most of the in vitro studies on differential therapy response in the more common NHL subtypes have addressed chemoresistance to the combined $\mathrm{CHOP}$ cocktail, but not directly for the individual drugs. Consequently, specific mechanisms that relate to GC resistance in NHL remain to be identified. In recent years, novel therapies for relapsed/refractory disease in NHL involve CAR T-cell therapy and small molecule inhibitors, such as Bruton's tyrosine kinase inhibitor ibrutinib, and several phosphatidylinositol 3-kinase (PI3K) and mTOR inhibitors.

Multiple myeloma (MM) is the second most common hematologic malignancy worldwide and two-thirds of the patients diagnosed with MM are above 65 years of age. MM is a heterogeneous clonal plasma cell proliferative disorder, which is almost always preceded by an asymptomatic premalignant stage, termed monoclonal gammopathy of undetermined significance. Diagnosis of MM is based on clinicopathological manifestations of serious end-organ damage, such as osteolytic bone lesions and renal failure ${ }^{[29]}$. MM is still not curable, and autologous SCT remains the standard treatment option for the younger and fit MM patients. As part of the induction therapy before SCT and for MM patients not eligible for SCT, different chemotherapeutic regimens in combination with proteasome inhibitors, immunomodulatory drugs (IMiDs) and GCs have clearly improved the prognosis ${ }^{[30,31]}$. Thus, GCs combined with IMiDs form the cornerstone drugs in many treatment regimens and GC monotherapy induces apoptosis in primary MM cells and in MM cell lines ${ }^{[32]}$.

\section{MECHANISM OF ACTION OF GCS}

The GR is composed of a N-terminal transactivation domain, a central DNA-binding domain and a C-terminal ligand-binding domain ${ }^{[33,34]}$. The DNA-binding domain contains two zinc-finger motifs that 


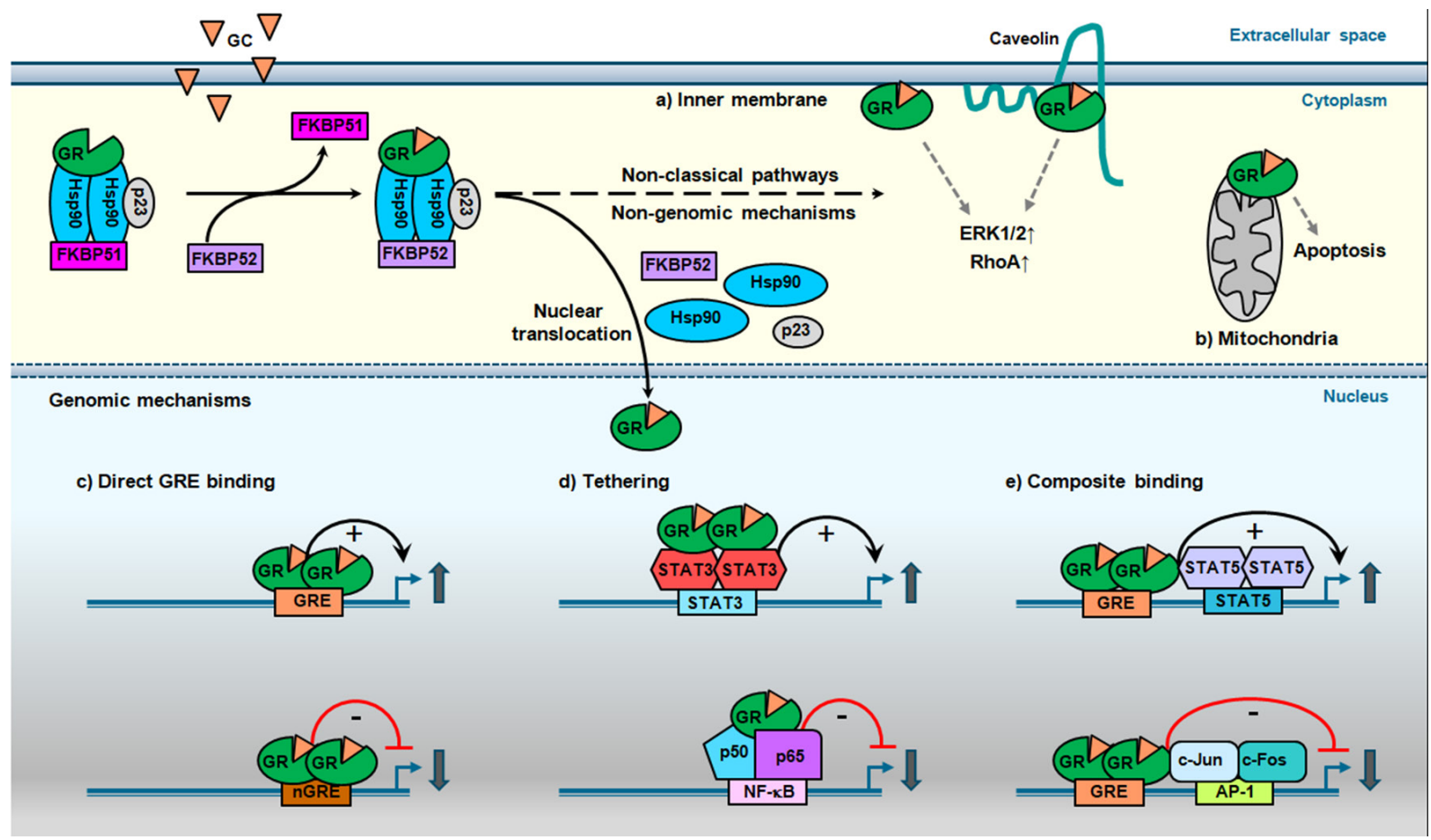

Figure 1. Mechanisms of GR action upon GC stimulation. Upon glucocorticoid (GC) binding, the cytoplasmic glucocorticoid receptor (GR), in complex with accessory proteins Hsp90, p23 and FKBP51, undergoes a conformational change and interacts with FKBP52. This results in dissociation of the multiprotein complex and facilitates subsequent GR signaling. The classical pathway involves genomic mechanisms of gene regulation by GR, while the non-classical pathway results in: a) inner membrane localization of GR, which can lead to ERK1/2 and RhoA activation; b) translocation of GR to mitochondria where it results in inhibition of apoptosis in GC-sensitive cells. Nuclear translocation of GR enhances or represses transcription of target genes by $\mathrm{C}$ ) direct binding to glucocorticoid responsive element (GRE) or negative GRE (nGRE) sites; d) tethering to other transcription factors without direct GRE interaction; e) or in a composite manner, which involves adjacent GRE binding

recognize and bind specific target DNA sequences, termed glucocorticoid- responsive elements (GREs) ${ }^{[35,36]}$. In the absence of GCs, the GR is primarily present in the cytoplasm as part of a larger multiprotein complex that includes the chaperone protein HSP90, p23 and immunophilin-related co-chaperone FKBP51 ${ }^{[37,38]}$, which keep GR in an inactive state. Binding of GCs yields a conformational change in the GR with rearrangement of the multiprotein complex, exposure of the nuclear localization signals and nuclear import ${ }^{[39]}$. Within the nucleus, the receptor dimerizes and binds to GREs to stimulate expression of target genes [Figure 1]. These conventional GREs belong to a family of imperfect palindromes consisting of two inverted hexameric half-site motifs (AGAACA) separated by 3 base pairs, which facilitate GR dimerization on the element ${ }^{[36]}$. Alternatively, GR associates with so-called negative GREs (nGREs) to repress gene transcription ${ }^{[40,41]}$. These elements contain the consensus sequence CTCC $(n)_{0-2}$ GGAGA that differs dramatically from the activating sequences. Upon DNA binding, conformational changes within GR lead to the recruitment of coregulators and chromatin-remodeling complexes that influence the activity of RNA polymerase II. Both the type of ligand and the GRE sequence itself can dictate the specific assembly and function of cofactors depending on the alterations induced in the receptor structure ${ }^{[42,43]}$. Interestingly, certain noncoding RNA fragments, such as Gas5, may act as decoy GRE, thus competing with DNA GREs for binding to GR ${ }^{[4]}$.

GR is also able to regulate gene transcription through physical association with other transcription factors, which can completely rely on GR tethering to these DNA-bound proteins or involve GR binding to both a GRE and the transcription factor on an adjacent site in a composite manner. The interaction of GR with the transcription factors NF- $\mathrm{KB}$ (GR tethering) and AP-1 (composite binding) inhibits their activity ${ }^{[45-49]}$, which accounts largely for the anti-inflammatory and immune-suppressive effects of GCs. This negative 
regulation by GR tethering (also together with SMAD3, POU2F1 and T-bet) and composite binding (including also C/EBP $\beta$, GATA1) is known as transrepression and is believed to involve the activity of GR monomers ${ }^{[50]}$. In contrast to these inhibitory effects, the interaction of GR with STAT3 and STAT5 transcription factors, either apart from or in conjunction with GRE binding, may enhance transcriptional activation of certain target genes ${ }^{[51-53]}$.

Finally, GR can sometimes undergo non-canonical activation and can be transcriptionally active in the absence of ligand, or mediate transcription-independent effects even in the presence of ligand ${ }^{[54,55]}$. These rapid non-classical GR effects relate to the presence of GR on the inner cell surface and stimulation of RhoA signaling ${ }^{[56]}$, or through direct activation of extracellular signal regulated kinase-1/2 (ERK1/2 $)^{[57,58]}$. In fact, cooperation between non-classical and classical GC signaling has been described, where the slower acting classical GC signaling mediates many of the physiological important responses ${ }^{[58]}$. Additional nongenomic mechanism includes translocation of GR into mitochondria specifically in lymphoid cells, which has been shown to correlate with GC-mediated apoptosis in thymocytes and absent in GC-resistant T cell lymphomas ${ }^{[59,60]}$.

\section{ALTERATIONS IN GR EXPRESSION AND FUNCTION CONTRIBUTE TO GC RESISTANCE}

The human NR3C1 gene is located on chromosome 5q31-32 and composed of nine exons. Functionally distinct GR isoforms can be generated by alternative splicing and translation initiation ${ }^{[6]}$. Alternative splicing that occurs at the $3^{\prime}$ end of the $\mathrm{NR} 3 \mathrm{C} 1$ gene generates the receptor isoforms GR $\alpha$ and GR $\beta$, which differ at their extreme C-termini. The GR $\alpha$ protein encodes the prototypic functionally active receptor, while the splice variant GR $\beta$ utilizes an alternative splice acceptor site in exon 9, yielding a shorter protein with a distinct 15 -amino acid stretch at the $\mathrm{C}$ terminus. This unique GR $\beta$ sequence abrogates ligand binding, and yields a constitutive nuclear isoform that has been reported to act as a dominant-negative inhibitor of GR $\alpha$ on genes both positively and negatively regulated by GCs ${ }^{[62,63]}$, although this has been disputed by others ${ }^{[64-66]}$. In fact, subsequent studies demonstrated that GR $\beta$ can directly induce and repress gene expression independent GR $\alpha$ transcriptional activity ${ }^{[6]]}$. Thus, by its ability to regulate gene expression, alterations in the expression level of GR $\beta$ may modulate the cellular sensitivity to GCs ${ }^{[6,69]}$. Increased levels of GR $\beta$ have been observed in a single case of GC-resistant CLL ${ }^{[70]}$, and lower GR $\alpha$ :GR $\beta$ mRNA expression ratios correlate with reduced sensitivity towards GC-induced apoptosis in childhood ALL ${ }^{[71]}$.

Besides GR $\beta$, several additional GR isoforms arise due to alternative splicing of the NR3C1 gene that can impact GC signaling. GRy originates from the use of an alternative splice donor site in the intron separating exon 3 and 4, which yields an insertion of a single arginine residue between the two zinc-fingers of the DNA-binding domain ${ }^{[72]}$. This widely expressed GR $\gamma$ isoform binds GCs and DNA with a similar capacity as GR $\alpha$, but its ability to activate GC-responsive reporters is compromised, and GR $\gamma$ exhibits a distinct transcriptional profile compared to $\mathrm{GR}{ }^{[36]}$. The role of GR $\gamma$ in mediating GC therapy resistance in lymphoid malignancies has not been firmly established. Two studies reported lower steady-state and GC-induced GR $\gamma$ mRNA levels in ALL leukemic blasts of prednisone good responders (PGR) compared to prednisone poor responders (PPR) ${ }^{[73,74]}$, while others showed that GR $\gamma$ mRNA induction in vivo in childhood ALL patients was more rapid and higher in PGR compared to PPR ${ }^{[75]}$. Two additional splice variants exist that lack large regions of the ligand-binding domain, termed GR-A and GR-P. Little is known about GR-A, but GR-P appears to be a predominant receptor variant in lymphoid malignancies, including $\mathrm{MM}^{[76,77]}$, but not exclusively in GC-refractory cases.

In a recent study, none of the alternative splicing variants showed a correlation with GC sensitivity in BCP-ALL, but only GR $\alpha$ played a central role in GC-mediated pro-apoptotic activity ${ }^{[78]}$. Thus, it seems that the relative abundance of GR $\alpha$ in comparison to the other isoforms is one of the more relevant determinants for GC responses. Acquired GC resistance in cancer patients may relate to inter-individual differences in 
the functional GR $\alpha$ pool before receiving therapy or reduced upon GC treatment. In fact, GC-dependent regulation of the NR3C1 gene is one of the critical determinants of GC sensitivity and resistance ${ }^{[79-81]}$. Thus, while most tissues show negative auto-regulation of $\mathrm{NR} 3 \mathrm{C} 1$, the promoter is positively regulated in GCsensitive lymphoid cells. Both promoter/enhancer DNA elements-dependent and -independent mechanisms have been proposed to be involved in the repression of GR $\alpha$ mRNA expression ${ }^{[82-84]}$. Next to altered mRNA expression, a block in transcription elongation of $N R 3 C 1$ has been linked to GC resistance in $\mathrm{MM}^{[85]}$. In BCP-ALL, focal NR3C1 deletions and inactivating mutations have been identified that contribute to a diminished pool of functional GR $\alpha^{[86,87]}$, which are often relapse-associated ${ }^{[8,89]}$. Furthermore, microRNAs miR-130b, miR-142-3p and miR-124 targeting 3'UTR of GR $\alpha$ in MM and ALL, promote GC resistance by downregulation of GR $\alpha$ mRNA transcripts ${ }^{[90-92]}$. In addition, proteasome-mediated degradation of the $\mathrm{GR} \alpha$ protein results in increased turnover of the receptor ${ }^{[93]}$. Another pathway that regulates GR levels is the NLRP3-CASP1 inflammasome, and increased levels of NLRP3 and CASP1 expression in GC-resistant and relapsed ALL samples due to promoter hypomethylation of these genes promote GR cleavage and GC resistance [Figure 2 and Table 1] ${ }^{[94]}$.

An additional mechanism that contributes to even a larger diversity of GR proteins results from alternative translation initiation of the GR mRNA transcripts ${ }^{[95,96]}$. From the classic full-length GR $\alpha$ isoform, eight proteins can be generated due to alternative AUG start codons with a progressively shorter N-terminal transactivation domain (GR $\alpha-A, G R \alpha-B, G R \alpha-C 1, G R \alpha-C 2, G R \alpha-C 3, G R \alpha-D 1, G R \alpha-D 2$ and $\mathrm{GR} \alpha-\mathrm{D} 3)^{[61]}$. Each of the other GR splice variants (GR $\beta$, GR $\gamma$, GR-A and GR-P) are also expected to give rise to similar translational isoforms. For the GR $\alpha$ translational isoforms, no significant differences have been observed in ligand affinity or their capacity to bind to GREs following GC stimulation ${ }^{[97]}$. However, the subcellular localization of the translational isoforms is different, with GR $\alpha$-D residing constitutively within the cell nucleus, while the other isoforms are predominantly cytoplasmic in the absence of ligands ${ }^{[95]}$. Notably, cells expressing GR $\alpha-C$ are most sensitive to GC-induced cell killing, whereas cells expressing GR $\alpha-\mathrm{D}$ are the most resistant ${ }^{[97,98]}$. These phenotypes correlate with the gene regulatory profiles, where the GR $\alpha$-C isoform is the most active in the ability to enhance transcription of GC-responsive reporter and endogenous genes ${ }^{[05,97]}$.

\section{GC RESISTANCE BY INTRINSIC INHIBITION OF APOPTOSIS}

The process of programmed cell death or apoptosis is characterized by the activity of caspases that can be activated by two main pathways ${ }^{[99]}$. The intrinsic mitochondrial pathway relies on mitochondrial outer membrane permeabilization and release of proteins from the mitochondrial intermembrane space. Among these, cytochrome $\mathrm{C}$ associates with Apaf-1 and the initiator caspase-9, which leads to activation of effector caspase-3 and caspase-7. The BCL2 family act as central regulators of mitochondrial outer membrane permeabilization leading to the irreversible release of intermembrane space proteins, subsequent caspase activation and apoptosis ${ }^{[100]}$. The BCL2 family is divided into three groups based on their primary function: (1) anti-apoptotic proteins (BCL2, BCL-X, BCL-W, MCL1, BFL1/A1); (2) pro-apoptotic pore-formers (BAX, BAK, BOK); and (3) pro-apoptotic $\mathrm{BH} 3$-only proteins (BAD, BID, BIK, BIM, BMF, HRK, NOXA, and PUMA). All BCL2 family proteins contain a $\mathrm{BH} 3$ domain, which represents one out of four $\mathrm{BH}$ domains involved in interactions between these proteins. Both the anti-apoptotic and pore-forming proteins contain all four $\mathrm{BH}$ domains (multi-BH domain proteins), while the $\mathrm{BH}$ 3-only proteins are subdivided into activator (BIM, BID, PUMA) and sensitizer (BAD, NOXA, BIK, BMF, HRK) proteins ${ }^{[101]}$. The second apoptosis pathway is the extrinsic pathway, which is dominated by signaling through death ligands, as FasL and TNF, and is not directly involved in GC-induced apoptosis.

In several subtypes of NHL, BCL2 protein expression is increased due to $\mathrm{t}(14 ; 18)(\mathrm{q} 32 ; \mathrm{q} 21)$ translocations involving the BCL2 gene. DLBCL positive for both c-MYC and BCL2 translocations, called double-hit 


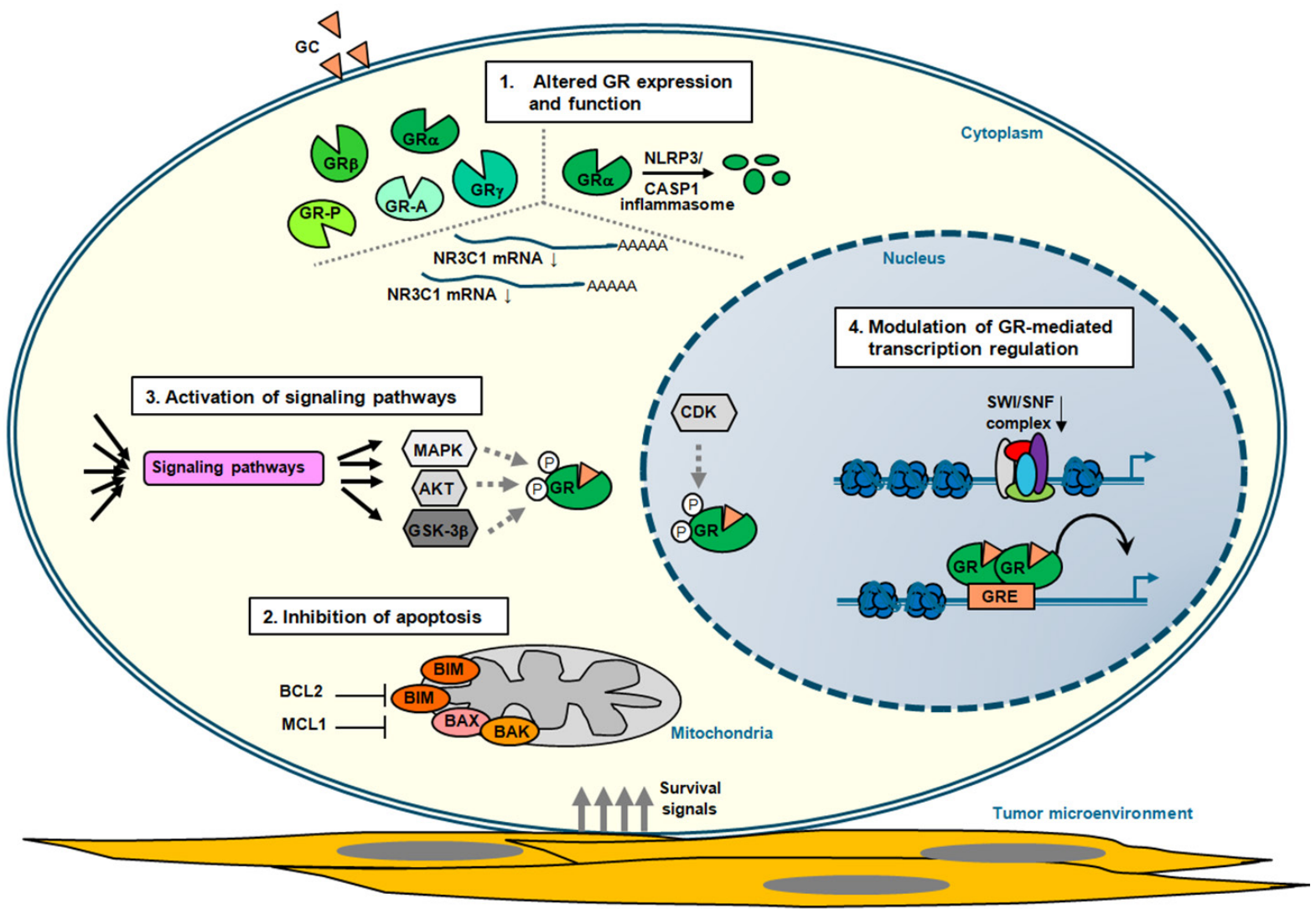

Figure 2. Mechanisms of GC resistance in lymphoid malignancies. Schematic representation of the four main mechanisms that contribute to glucocorticoid (GC) resistance in lymphoid tumor cells (see also Table 1). These represent altered: glucocorticoid receptor (GR) expression due to alternative splicing and translation initiation (see text) and function; inhibition of apoptosis by deregulated expression of proteins involved in programmed cell death and through interaction with components of the tumor microenvironment that promote survival signaling; activation of signaling pathways that in a direct or indirect manner alter GR-mediated cell death (see text); and modulation of GR-mediated transcription regulation, thereby altering the expression of critical regulators of GC therapy sensitivity

lymphoma, display inferior outcome after R-CHOP treatment ${ }^{[102]}$, probably by suppressing in part GCinduced apoptosis in these lymphoma cells. Transcriptional induction of the pro-apoptotic BH3-only protein BIM by GCs has been observed in many lymphoid cell types ${ }^{[103]}$, and is considered to be one of the key mediators for the selective pro-apoptotic response in lymphoid cells to GCs. However, the mere up-regulation of the pro-apoptotic BIM protein is insufficient for initiating apoptosis, and requires activation through post-translational modifications and interactions with other proteins ${ }^{[104]}$. BIM is involved in GC-induced cell killing in $\mathrm{ALL}^{[105-110]}, \mathrm{CLL}^{[111,112]}$, and $\mathrm{MM}^{[113-116]}$. FOXO3a is a critical regulator of BIM expression ${ }^{[117,118]}$, and inhibition of the FOXO3a/BIM axis is observed in GC-resistant T-ALL ${ }^{[119]}$, but also epigenetic silencing of $B I M(B C L 2 L 11)$ expression is detected in pediatric ALL poor prednisone responders ${ }^{[120]}$. Opposing mechanisms of $B I M$ and $B C L 2$ gene regulation in dexamethasone-sensitive and -resistant pediatric ALL xenografts correlates with differential response towards GC-induced apoptosis ${ }^{[121]}$. In addition, increased levels of anti-apoptotic protein MCL1 correlate with GC resistance in ALL ${ }^{[122-125]}$. $M C L 1$ and pro-apoptotic gene NOXA are direct targets of GR and modulate the response to GCs ${ }^{[126]}$. In plasma cell malignancies MM and Waldenström macroglobulinemia, MCL1 and BCL2 are associated with decreased sensitivity towards $\mathrm{GCs}^{[127]}$.

Besides aberrant expression of proteins directly involved in programmed cell death, there are also genetic alterations that can mediate therapy resistance by altering the expression of central regulators of the mitochondrial apoptosis process [Table 1]. Loss-of-function mutations of polycomb repressive 
Table 1. Mechanisms contributing to glucocorticoid resistance in lymphoid malignancies

\begin{tabular}{lll}
\hline Type of mechanism & \multicolumn{1}{c}{ Specific examples } & Ref. \\
\hline Altered GR expression and & Differential expression of alternatively spliced and translated GR isoforms & {$[68-71,73-78,97,98]$} \\
function & Transcriptional autoregulation of NR3C1 & {$[80,81,85]$} \\
& NR3C1 gene deletions and mutations & {$[86-89]$} \\
& Regulation of GR by microRNAs & {$[90-92]$} \\
& Degradation of GR by NLRP3-CASP1 inflammasome & {$[94]$} \\
Inhibition of apoptosis & BCL2 translocation & {$[102]$} \\
& Differential BIM expression & {$[105-121]$} \\
& Altered MCL1 expression & {$[122-127]$} \\
& Loss-of-function mutations in PRC2 complex proteins (EZH2, EED, SUZ12) & {$[128]$} \\
& Survival signals by stromal cells & {$[130,131]$} \\
Activation of signaling & MAPK pathway & {$[140]$} \\
pathways & CDK-dependent GR phosphorylation & {$[146,147]$} \\
& PI3K/AKT pathway & {$[148-153]$} \\
& LCK signaling & {$[156]$} \\
& JAK/STAT pathway & {$[160]$} \\
& Metabolism/mTOR signaling & {$[161-163]$} \\
NoTCH1 pathway & {$[165-167]$} \\
transcription regulation & Reduced expression of SWI/SNF chromatin remodeling complex proteins & {$[122,171]$} \\
& IKZF1, BTG1, TBLTXR1 and CREBBP gene deletions/mutations affect GR target & {$[179-187]$}
\end{tabular}

GR: glucocorticoid receptor; MCL: mantle cell lymphoma; PI3K: phosphatidylinositol 3-kinase; CDK: cyclin-dependent kinase

complex (PRC2), which includes EZH2, EED and SUZ12, inhibit mitochondrial apoptosis in immature T lymphocytes, in part through upregulation of HSP90 family chaperone tumor necrosis factor receptorassociated protein 1 (TRAP1) ${ }^{[128]}$. TRAP1 regulates a variety of cellular processes, and is involved in the protection against DNA damage and apoptosis induced by oxidants and other forms of cellular stress ${ }^{[129]}$. Consequently, loss of PRC2 function in mouse T cell progenitors and T-ALL cells results in mitochondrial apoptosis resistance towards several cytotoxic chemotherapeutics, including dexamethasone ${ }^{[128]}$. In addition, localization of malignant lymphoid cells within the bone marrow (BM) niche provides survival signals via cytokines and growth factors, as well as interaction with specific components in the tumor microenvironment, which protects cells from GC-induced apoptosis. For instance, epithelial membrane protein 1 (EMP1) has been directly linked to inferior prognosis in pediatric ALL, and EMP1 contributes to GC resistance mediated through adhesion to mesenchymal stromal cells ${ }^{[130]}$. Also for MM, protective effects of pro-survival cytokines from the BM microenvironment confer therapy resistance ${ }^{[131]}$.

\section{SIGNALING PATHWAYS THAT IMPACT GC RESISTANCE}

GR $\alpha$ is subject to various post-translational modifications, which include phosphorylation, sumoylation, acetylation and ubiquitination ${ }^{[61]}$. Studies have mainly linked alterations in GR $\alpha$ phosphorylation status to GC resistance, although sumoylation seems also to play an important role in regulating GR activity ${ }^{[132]}$. Ligand-dependent GR phosphorylation significantly affects the cellular response to steroids by its ability to modulate the cellular trafficking of the receptor, its protein stability, and transcriptional activity ${ }^{[133]}$. Several kinases have been shown to phosphorylate GR $\alpha$ primarily at the $\mathrm{N}$-terminal transactivation domain, which include mitogen activated protein kinases (MAPKs), cyclin-dependent kinases (CDKs), AKT/protein kinase $B$ as well as glycogen synthase kinase 3 beta $(\mathrm{GSK}-3 \beta)$ and alpha $(\mathrm{GSK} \alpha)^{[134]}$.

MAPKs constitute the largest subfamily of serine/threonine kinases that transduce extracellular signals into intracellular processes and altered gene expression ${ }^{[135]}$. In the context of GR signaling, p38 MAPK, c-Jun N-terminal kinase (JNK) and ERK have been identified as regulators of GR function. p38 MAPKmediated phosphorylation of GR on serine residue 211 (Ser211) enhances its target gene regulation 
and facilitates GC-induced apoptosis ${ }^{[136]}$, while JNK phosphorylates GR on Ser226 suppressing its transcriptional activity and blocking apoptosis ${ }^{[137,138]}$. Furthermore, p38 MAPK phosphorylates GR on Ser134 in response to stress, resulting in increased association with 14-3-3 proteins and selective target gene regulation ${ }^{[139]}$. Inhibition of the more upstream MAPK pathway members MEK2 and MEK4 increases the sensitivity to prednisolone in pediatric ALL, which seems to correlate with increased phospho-ERK levels and GC resistance at relapse ${ }^{[140]}$. ERK inhibition reduces Ser203 phosphorylation resulting in enhanced GR nuclear localization and GC-mediated target gene regulation ${ }^{[141]}$.

CDK proteins in complex with cyclins act as key regulators of the cell cycle, and several CDK complexes (i.e., cyclin A-CDK2, cyclin B-CDK2 and cyclin E-CDK2) phosphorylate GR on serine residues 203 and 211 (Ser203 and Ser211) ${ }^{[133,142]}$. CDK5 has no cell cycle regulatory function but is activated upon stress, and CDK5 phosphorylates GR on multiple serine residues (Ser203, Ser211 and Ser226) ${ }^{[143]}$. GR phosphorylated on Ser203 does not localize to the nucleus and is transcriptionally inactive ${ }^{[144]}$. GR phosphorylated on Ser211 displays the highest transcriptional activity and recruitment to GRE-containing promoters, while Ser226 is associated with a negative effect on transcription regulation ${ }^{[144,145]}$. In fact, lack of Ser211 phosphorylation has been directly linked to GC resistance in lymphoid cells ${ }^{[146]}$, and the combined ratio of activating Ser211 and inhibitory Ser226 phosphorylation of GR in CLL predicts GC-responses ${ }^{[147]}$.

The PI3K/AKT pathway plays a central role in regulating cell growth and survival of lymphoid cells downstream of B- (BCR) and T-cell receptor (TCR) signaling as well as cytokine receptor stimulation. Constitutive PI3K activation is frequently observed in lymphoid malignancies, including ALL, CLL and $\mathrm{MCL}^{[148,149]}$, which can be attributed to loss of PTEN function, or mutations that mimic BCR signaling. Pharmacologic inhibition of PI3K or AKT can overcome GC resistance in ALL ${ }^{[150-152]}$, which has been directly linked to inhibition of AKT1-mediated phosphorylation of GR $\alpha$ on Ser134 ${ }^{[152]}$. This results in cytoplasmic retention of GR $\alpha$ via interaction with 14-3-3 proteins, although AKT1 has also a positive effect on GR transcriptional activity within the nucleus ${ }^{[152,153]}$. Notably, recent studies show that PI3K/AKT/ mTOR pathway also affect GR phosphorylation at Ser211, inhibiting GR $\alpha$ nuclear import and shift GR $\alpha$ transcriptional activity towards gene transrepression in both lymphoid and epithelial cells ${ }^{[154,155]}$.

Activation of the PI3K pathway may also result through autocrine and paracrine release from cytokines in lymphoid tumors, and LCK hyperactivation in GC-resistant T-ALL results in upregulation of calcineurin/ nuclear factor of activated T cells signaling, which triggers interleukin-4 (IL-4) overexpression ${ }^{[156]}$. LCK inhibition can revert this GC resistance and induce cell death in T-ALL cells insensitive for GC treatment. To the converse, IL-4 stimulation alone is sufficient to impose GC resistance in dexamethasone-sensitive T-ALL cell lines ${ }^{[156]}$, most likely through activation of the PI3K/AKT pathway. GSK3 $\beta$, known to participate in immunity and metabolism regulation, phosphorylates GR on Ser404 upon GC treatment, thereby adjusting the repressive effects of GR on NF- $\mathrm{KB}^{[157]}$. However, GSK3 $\beta$ has also a strong pro-apoptotic function and is negatively regulated by the PI3K/AKT pathway. In part, this relates to destabilization of MCL1 through GSK3 $\beta$-mediated phosphorylation ${ }^{[158]}$, thereby influencing the sensitivity towards GCinduced apoptosis in an indirect manner. GSK $3 \alpha$ on its turn interacts with GR $\alpha$ in the absence of ligand. Upon exposure to GCs, GSK3 $\alpha$ dissociates from GR $\alpha$ and interacts with pro-apoptotic protein BIM, and this interaction is also observed for GSK $3 \beta^{[159]}$. Thus, inhibition of GSK activity contributes to GC resistance at different levels.

Other pathways that impact GC responses in lymphoid malignancies are JAK/STAT, mTOR and NOTCH1 signaling. Activation of the JAK/STAT pathway is commonly observed both in ALL and mature lymphoid malignancies. Inhibition of JAK/STAT signaling in T-ALL overcomes IL-7-induced GC resistance in a subset of T-ALL ${ }^{[160]}$. Interestingly, in ALL, GC resistance has been directly associated with the metabolic state of these cells, including upregulation of glycolysis, oxidative phosphorylation and activation of mTOR 
signaling ${ }^{[161,162]}$. Inhibition of mTOR by rapamycin, blocks upregulation of MCL1, thereby facilitating the pro-apoptotic action of $\mathrm{BIM}^{[123]}$. However, it has been argued that the glycolytic reserves are relative low in BCP-ALL, resulting in the constitutive activation of the LKB1-AMPK energy-stress-sensor-pathway ${ }^{[163]}$. B-lymphoid transcription factors are responsible for this metabolic state and set the threshold for GC responses, in part by positively regulating $N R 3 C_{1} 1$ levels ${ }^{[163]}$. On the other hand, it has been reported that suppression of B cell development genes is required for GC-induced cytotoxicity ${ }^{[164]}$. In T-ALL, NOTCH1 activation is frequently observed, which has been shown to impair GC signaling ${ }^{[165]}$. Combined expression of NOTCH1 and BCL2 results in GC-resistant T cell lymphoma ${ }^{[166]}$. In GC-resistant T-ALL, abrogation of active NOTCH1 signaling by gamma-secretase inhibitors reverses GC resistance ${ }^{[165]}$. Notably, NOTCH1 target gene HES1 acts as a negative regulator of GR-mediated gene transcription through binding to adjacent $\mathrm{N}$-boxes (CACNAG) in a composite manner, and GC signaling requires silencing of HES1 $\operatorname{expression}^{[167]}$.

\section{GC RESISTANCE THROUGH MODULATION OF GR-DEPENDENT TRANSCRIPTION REGULATION}

GC-induced RNA transcription within the nucleus heavily depends on specific protein-protein interactions and chromatin context, which together control GR-mediated gene regulation ${ }^{[168]}$. Binding of agonistliganded GR to conventional GREs confers transcriptional transactivation through association with co-activators, like SRC1, TIF2/SRC2 and SRC $3^{[169]}$, as well as $\mathrm{CBP} / \mathrm{p} 300^{[157]}$. GR can also recruit BRG1, the central ATPase of the SWI/SNF chromatin remodeling complex, which facilitates the formation of transcriptional pre-initiation complex and transcriptional transactivation ${ }^{[170]}$. Several of the core subunits of the SWI/SNF complex, i.e., SMARC4A, SMARCB1 and ARID1A, are lower expressed in GC-resistant $\mathrm{ALL}^{[122,171]}$. Coactivator function of GR on selective target genes can also involve association with Mediator subunits MED1 and MED14 ${ }^{[172,173]}$. Transcriptional suppression of GR occurs via transrepression of AP-1/ $\mathrm{NF}-\kappa \mathrm{B}$ sites ${ }^{[168,174]}$, blocking chromatin accessibility of AP-1 and NF- $\mathrm{B}$ through activation of powerful negative regulators of the inflammatory signaling cascade ${ }^{[175]}$, or direct GR association with nGREs ${ }^{[40,176]}$. Negative enhancers selective facilitate GR recruitment of the co-repressor GRIP ${ }^{[176,177]}$. Furthermore, negative autoregulation of $\mathrm{NR} 3 \mathrm{C} 1$ expression by GC is mediated by NCoR repression complex through long-range chromatin interactions with a nGRE in exon 6 of $\mathrm{NR}_{3} \mathrm{Cl}^{[83]}$. On the other hand, histone H3 lysine-9 methyltransferase G9a/KMT1C mediates both coactivator and corepressor function for hormoneactivated $\mathrm{GR}^{[178]}$.

Attenuation of GR-mediated transcription regulation both at the level of GC-induced gene activation and repression has been observed in IKZF1-deleted BCP-ALL, which is associated with inferior treatment outcome, relapsed disease and reduced GC-sensitivity ${ }^{[179-181]}$. Focal BTG1 deletions further enhance this phenotype ${ }^{[182]}$, which correlates with the ability of BTG1 to regulate GR-dependent transcription ${ }^{[183]}$. TBL1XR1 gene deletions are enriched in relapsed BCP-ALL and TBL1XR1 knockdown confers GC resistance in BCP-ALL cell lines ${ }^{[184]}$. TBL1XR1 is a member of the NCoR complex and responsible for NCoR degradation ${ }^{[185,186]}$. TBL1XR1 silencing yields decreased GR recruitment at gene regulatory regions, which is accompanied by increased NCoR1 residing on the promoters of GC-responsive genes with increased recruitment of $\mathrm{HDAC}^{[184]}$. In addition, inactivating mutations in $C R E B B P$, which encodes the important GR transcriptional coactivator CBP, have been detected in relapsed ALL, and impair GC-induced transcriptional responses ${ }^{[187]}$.

Next to regulation at the level of GR activity itself, selective differences in chromatin structure also pre-determine effective GR binding and ensure appropriate transcription regulation ${ }^{[188,189]}$. Notably, lymphocyte-specific chromatin accessibility has been linked to acquired GC resistance in ALL for individual patients that display reduced sensitivity to GCs as well as for non-lymphoid cell types that are intrinsically resistant to GC-induced apoptosis ${ }^{[190]}$. This study revealed that the selective induction of pro- 
apoptotic gene BIM(BCL2L11) in GC-sensitive ALL samples correlates with a defined open and active chromatin structure at an intronic GR-binding region within the BIM locus together with recruitment of the chromatin architectural protein CTCF to this site. Reduced accessibility of the intronic BIM locus in GC-resistant ALL samples was associated with increased levels of DNA methylation and histone acetylation, which could be reversed by DNA demethylating drug azacitidine and histone deacetylase (HDAC) inhibitor vorinostat, respectively ${ }^{[120,190]}$.

\section{CONCLUSION AND PERSPECTIVE}

In recent years, a deeper understanding on the mechanism of action of GC signaling in normal and malignant lymphoid cells has provided valuable insight into the pathways that regulate GR function and the selectivity of target gene regulation. Many of these physiological processes dictate the sensitivity and specificity of GC responses. To the converse, functional studies linked to genetic aberrations or altered expression signatures associated with inferior prognosis and GC resistance in different lymphoid malignancies have also contributed to a better understanding of GR regulation [Table 1]. Thus, acquired GC often results from the formation of highly resistant leukemia or lymphoma-associated subclones that arose even in the absence of GC-induced selection pressure, but provided selective growth advantage during the development of the tumor. In many cases, the genetic aberrations present in these subclones are maintained or enriched at time of relapse, since they impose specific survival cues during treatment by conferring partial resistance to GC-induced apoptosis. For some lymphoid malignancies, such as ALL, many of these relapse-associated gene mutations or copy number abnormalities have been identified, and functional studies are underway to address the exact mechanisms underlying GC therapy resistance for each of the affected genes and pathways. However, there are still clinically relevant biomarkers associated with inferior prognosis and GC resistance in other lymphoid malignancies that remain to be identified. In the near future, most of these relapse-enriched or relapse-specific genomic aberrations will be identified by employing whole exome sequencing and transcriptome analyses in the different types of lymphoid malignancies.

The challenges for the near future to improve treatment outcome in high-risk patients and for hematological cancers that are still incurable is to target the mechanisms that impose therapy resistance and provide precision medicine that is tailored to the individual (epi-)genetic and immunological context of each tumor. Therapies breaking GC resistance will be beneficial for those treatment regimens that are relatively more dependent on the cytotoxic activity of synthetic GCs, as is probably the case in ALL and MM. The development of different targeted small molecule inhibitors and modalities of immunotherapy in combination with predictive biomarkers for personalized treatment will hopefully increase the overall survival rate of hematological cancer patients.

\section{DECLARATIONS}

\section{Authors' contributions}

The author contributed solely to the article.

\section{Availability of data and materials}

Not applicable.

\section{Financial support and sponsorship}

This work was supported by KWF (11137).

\section{Conflicts of interest}

The author declared that there are no conflicts of interest. 


\section{Ethical approval and consent to participate}

Not applicable.

\section{Consent for publication}

Not applicable.

\section{Copyright}

(c) The Author(s) 2019.

\section{REFERENCES}

1. Sapolsky RM, Romero LM, Munck AU. How do glucocorticoids influence stress responses? Integrating permissive, suppressive, stimulatory, and preparative actions. Endocr Rev 2000;21:55-89.

2. Rhen T, Cidlowski JA. Antiinflammatory action of glucocorticoids--new mechanisms for old drugs. N Engl J Med 2005;353:1711-23.

3. Lu NZ, Wardell SE, Burnstein KL, Defranco D, Fuller PJ, et al. International Union of Pharmacology. LXV. The pharmacology and classification of the nuclear receptor superfamily: glucocorticoid, mineralocorticoid, progesterone, and androgen receptors. Pharmacol Rev 2006;58:782-97.

4. Cole TJ, Blendy JA, Monaghan AP, Krieglstein K, Schmid W, et al. Targeted disruption of the glucocorticoid receptor gene blocks adrenergic chromaffin cell development and severely retards lung maturation. Genes Dev 1995;9:1608-21.

5. Pearson OH, Eliel LP. Use of pituitary adrenocorticotropic hormone (ACTH) and cortisone in lymphomas and leukemias. J Am Med Assoc 1950;144:1349-53.

6. Pufall MA. Glucocorticoids and cancer. Adv Exp Med Biol 2015;872:315-33.

7. Tissing WJ, Meijerink JP, den Boer ML, Pieters R. Molecular determinants of glucocorticoid sensitivity and resistance in acute lymphoblastic leukemia. Leukemia 2003;17:17-25.

8. Iacobucci I, Mullighan CG. Genetic basis of acute lymphoblastic leukemia. J Clin Oncol 2017;35:975-83.

9. Arico M, Basso G, Mandelli F, Rizzari C, Colella R, et al. Good steroid response in vivo predicts a favorable outcome in children with T-cell acute lymphoblastic leukemia. The Associazione Italiana Ematologia Oncologia Pediatrica (AIEOP). Cancer 1995;75:1684-93.

10. Dordelmann M, Reiter A, Borkhardt A, Ludwig WD, Gotz N, et al. Prednisone response is the strongest predictor of treatment outcome in infant acute lymphoblastic leukemia. Blood 1999;94:1209-17.

11. Schrappe M, Arico M, Harbott J, Biondi A, Zimmermann M, et al. Philadelphia chromosome-positive $(\mathrm{Ph}+)$ childhood acute lymphoblastic leukemia: good initial steroid response allows early prediction of a favorable treatment outcome. Blood 1998;92:2730-41.

12. Bassan R, Bourquin JP, DeAngelo DJ, Chiaretti S. New approaches to the management of adult acute lymphoblastic leukemia. J Clin Oncol 2018; doi: 10.1200/JCO.2017.77.3648.

13. Terwilliger T, Abdul-Hay M. Acute lymphoblastic leukemia: a comprehensive review and 2017 update. Blood Cancer J $2017 ; 7:$ e577.

14. Smolej L. The role of high-dose corticosteroids in the treatment of chronic lymphocytic leukemia. Expert Opin Investig Drugs 2012;21:1009-17.

15. Bosanquet AG, McCann SR, Crotty GM, Mills MJ, Catovsky D. Methylprednisolone in advanced chronic lymphocytic leukaemia: rationale for, and effectiveness of treatment suggested by DiSC assay. Acta Haematol 1995;93:73-9.

16. Bowen DA, Call TG, Jenkins GD, Zent CS, Schwager SM, et al. Methylprednisolone-rituximab is an effective salvage therapy for patients with relapsed chronic lymphocytic leukemia including those with unfavorable cytogenetic features. Leuk Lymphoma 2007;48:2412-7.

17. Dungarwalla M, Evans SO, Riley U, Catovsky D, Dearden CE, et al. High dose methylprednisolone and rituximab is an effective therapy in advanced refractory chronic lymphocytic leukemia resistant to fludarabine therapy. Haematologica 2008;93:475-6.

18. Castro JE, Sandoval-Sus JD, Bole J, Rassenti L, Kipps TJ. Rituximab in combination with high-dose methylprednisolone for the treatment of fludarabine refractory high-risk chronic lymphocytic leukemia. Leukemia 2008;22:2048-53.

19. Pileckyte R, Jurgutis M, Valceckiene V, Stoskus M, Gineikiene E, et al. Dose-dense high-dose methylprednisolone and rituximab in the treatment of relapsed or refractory high-risk chronic lymphocytic leukemia. Leuk Lymphoma 2011;52:1055-65.

20. Yao QM, Li PP, Liang SM, Lu K, Zhu XJ, et al. Methylprednisolone suppresses the Wnt signaling pathway in chronic lymphocytic leukemia cell line MEC-1 regulated by LEF-1 expression. Int J Clin Exp Pathol 2015;8:7921-8.

21. Gutierrez A Jr, Tschumper RC, Wu X, Shanafelt TD, Eckel-Passow J, et al. LEF-1 is a prosurvival factor in chronic lymphocytic leukemia and is expressed in the preleukemic state of monoclonal B-cell lymphocytosis. Blood 2010;116:2975-83.

22. Cirillo M, Reinke S, Klapper W, Borchmann S. The translational science of hodgkin lymphoma. Br J Haematol 2019;184:30-44.

23. Allen PB, Winter JN. Controversies in the approach to initial therapy of hodgkin lymphoma. Curr Oncol Rep 2019;21:39.

24. Eichenauer DA, Andre M, Johnson P, Fossa A, Casasnovas O, et al. Controversies in the treatment of classical hodgkin lymphoma. Hemasphere 2018;2:e149.

25. Armitage JO, Gascoyne RD, Lunning MA, Cavalli F. Non-Hodgkin lymphoma. Lancet 2017;390:298-310.

26. Recher C, Coiffier B, Haioun C, Molina TJ, Ferme C, et al. Intensified chemotherapy with ACVBP plus rituximab versus standard CHOP plus rituximab for the treatment of diffuse large B-cell lymphoma (LNH03-2B): an open-label randomised phase 3 trial. Lancet 
2011;378:1858-67.

27. Dunleavy K, Fanale MA, Abramson JS, Noy A, Caimi PF, et al. Dose-adjusted EPOCH-R (etoposide, prednisone, vincristine, cyclophosphamide, doxorubicin, and rituximab) in untreated aggressive diffuse large B-cell lymphoma with MYC rearrangement: a prospective, multicentre, single-arm phase 2 study. Lancet Haematol 2018;5:e609-17.

28. Flinn IW, van der Jagt R, Kahl B, Wood P, Hawkins T, et al. First-line treatment of patients with indolent non-hodgkin lymphoma or mantle-cell lymphoma with bendamustine plus rituximab versus R-CHOP or R-CVP: results of the BRIGHT 5-year follow-up study. J Clin Oncol 2019; doi: 10.1200/JCO.18.00605.

29. Rajkumar SV, Dimopoulos MA, Palumbo A, Blade J, Merlini G, et al. International myeloma working group updated criteria for the diagnosis of multiple myeloma. Lancet Oncol 2014;15:e538-48.

30. Blommestein HM, van Beurden-Tan CHY, Franken MG, Uyl-de Groot CA, Sonneveld P, et al. Efficacy of first-line treatments for multiple myeloma patients not eligible for stem cell transplantation - A Network Meta-analysis. Haematologica 2019; doi: 10.3324/ haematol.2018.206912.

31. Sekine L, Ziegelmann PK, Manica D, da Fonte Pithan C, Sosnoski M, et al. Frontline treatment for transplant-eligible multiple myeloma: a 6474 patients network meta-analysis. Hematol Oncol 2019;37:62-74.

32. Chauhan D, Anderson KC. Mechanisms of cell death and survival in multiple myeloma (MM): therapeutic implications. Apoptosis 2003;8:337-43.

33. Mangelsdorf DJ, Thummel C, Beato M, Herrlich P, Schutz G, et al. The nuclear receptor superfamily: the second decade. Cell 1995;83:835-9.

34. Wright AP, Zilliacus J, McEwan IJ, Dahlman-Wright K, Almlof T, et al. Structure and function of the glucocorticoid receptor. J Steroid Biochem Mol Biol 1993;47:11-9.

35. So AY, Cooper SB, Feldman BJ, Manuchehri M, Yamamoto KR. Conservation analysis predicts in vivo occupancy of glucocorticoid receptor-binding sequences at glucocorticoid-induced genes. Proc Natl Acad Sci U S A 2008;105:5745-9.

36. Meijsing SH, Pufall MA, So AY, Bates DL, Chen L, et al. DNA binding site sequence directs glucocorticoid receptor structure and activity. Science 2009;324:407-10.

37. Grad I, Picard D. The glucocorticoid responses are shaped by molecular chaperones. Mol Cell Endocrinol 2007;275:2-12.

38. Hahle A, Merz S, Meyners C, Hausch F. The many faces of FKBP51. Biomolecules 2019;9.

39. Ricketson D, Hostick U, Fang L, Yamamoto KR, Darimont BD. A conformational switch in the ligand-binding domain regulates the dependence of the glucocorticoid receptor on Hsp90. J Mol Biol 2007;368:729-41.

40. Surjit M, Ganti KP, Mukherji A, Ye T, Hua G, et al. Widespread negative response elements mediate direct repression by agonistliganded glucocorticoid receptor. Cell 2011;145:224-41.

41. Morrison N, Eisman J. Role of the negative glucocorticoid regulatory element in glucocorticoid repression of the human osteocalcin promoter. J Bone Miner Res 1993;8:969-75.

42. Lim HW, Uhlenhaut NH, Rauch A, Weiner J, Hubner S, et al. Genomic redistribution of GR monomers and dimers mediates transcriptional response to exogenous glucocorticoid in vivo. Genome Res 2015;25:836-44.

43. Hudson WH, Youn C, Ortlund EA. The structural basis of direct glucocorticoid-mediated transrepression. Nat Struct Mol Biol 2013;20:53-8.

44. Kino T, Hurt DE, Ichijo T, Nader N, Chrousos GP. Noncoding RNA gas5 is a growth arrest- and starvation-associated repressor of the glucocorticoid receptor. Sci Signal 2010;3:ra8.

45. Yang-Yen HF, Chambard JC, Sun YL, Smeal T, Schmidt TJ, et al. Transcriptional interference between c-Jun and the glucocorticoid receptor: mutual inhibition of DNA binding due to direct protein-protein interaction. Cell 1990;62:1205-15.

46. Jonat C, Rahmsdorf HJ, Park KK, Cato AC, Gebel S, et al. Antitumor promotion and antiinflammation: down-modulation of AP-1 (Fos/Jun) activity by glucocorticoid hormone. Cell 1990;62:1189-204.

47. Schule R, Rangarajan P, Kliewer S, Ransone LJ, Bolado J, et al. Functional antagonism between oncoprotein c-Jun and the glucocorticoid receptor. Cell 1990;62:1217-26.

48. Ray A, Prefontaine KE. Physical association and functional antagonism between the p65 subunit of transcription factor NF-kappa B and the glucocorticoid receptor. Proc Natl Acad Sci U S A 1994;91:752-6.

49. Nissen RM, Yamamoto KR. The glucocorticoid receptor inhibits NFkappaB by interfering with serine-2 phosphorylation of the RNA polymerase II carboxy-terminal domain. Genes Dev 2000;14:2314-29.

50. Cain DW, Cidlowski JA. Immune regulation by glucocorticoids. Nat Rev Immunol 2017;17:233-47.

51. Stocklin E, Wissler M, Gouilleux F, Groner B. Functional interactions between Stat5 and the glucocorticoid receptor. Nature 1996;383:726-8.

52. Zhang Z, Jones S, Hagood JS, Fuentes NL, Fuller GM. STAT3 acts as a co-activator of glucocorticoid receptor signaling. J Biol Chem 1997;272:30607-10.

53. Takeda T, Kurachi H, Yamamoto T, Nishio Y, Nakatsuji Y, et al. Crosstalk between the interleukin-6 (IL-6)-JAK-STAT and the glucocorticoid-nuclear receptor pathway: synergistic activation of IL-6 response element by IL-6 and glucocorticoid. J Endocrinol 1998;159:323-30.

54. Robertson S, Rohwer JM, Hapgood JP, Louw A. Impact of glucocorticoid receptor density on ligand-independent dimerization, cooperative ligand-binding and basal priming of transactivation: a cell culture model. PLoS One 2013;8:e64831.

55. Hapgood JP, Avenant C, Moliki JM. Glucocorticoid-independent modulation of GR activity: implications for immunotherapy. Pharmacol Ther 2016;165:93-113. 
56. Vernocchi S, Battello N, Schmitz S, Revets D, Billing AM, et al. Membrane glucocorticoid receptor activation induces proteomic changes aligning with classical glucocorticoid effects. Mol Cell Proteomics 2013;12:1764-79.

57. Gutierrez-Mecinas M, Trollope AF, Collins A, Morfett H, Hesketh SA, et al. Long-lasting behavioral responses to stress involve a direct interaction of glucocorticoid receptors with ERK1/2-MSK1-Elk-1 signaling. Proc Natl Acad Sci U S A 2011;108:13806-11.

58. Samarasinghe RA, Witchell SF, DeFranco DB. Cooperativity and complementarity: synergies in non-classical and classical glucocorticoid signaling. Cell Cycle 2012;11:2819-27.

59. Sionov RV, Cohen O, Kfir S, Zilberman Y, Yefenof E. Role of mitochondrial glucocorticoid receptor in glucocorticoid-induced apoptosis. J Exp Med 2006;203:189-201.

60. Talaber G, Boldizsar F, Bartis D, Palinkas L, Szabo M, et al. Mitochondrial translocation of the glucocorticoid receptor in doublepositive thymocytes correlates with their sensitivity to glucocorticoid-induced apoptosis. Int Immunol 2009;21:1269-76.

61. Oakley RH, Cidlowski JA. Cellular processing of the glucocorticoid receptor gene and protein: new mechanisms for generating tissuespecific actions of glucocorticoids. J Biol Chem 2011;286:3177-84.

62. Bamberger CM, Bamberger AM, de Castro M, Chrousos GP. Glucocorticoid receptor beta, a potential endogenous inhibitor of glucocorticoid action in humans. J Clin Invest 1995;95:2435-41.

63. Oakley RH, Jewell CM, Yudt MR, Bofetiado DM, Cidlowski JA. The dominant negative activity of the human glucocorticoid receptor beta isoform. Specificity and mechanisms of action. J Biol Chem 1999;274:27857-66.

64. de Lange P, Koper JW, Brinkmann AO, de Jong FH, Lamberts SW. Natural variants of the beta isoform of the human glucocorticoid receptor do not alter sensitivity to glucocorticoids. Mol Cell Endocrinol 1999;153:163-8.

65. Hecht K, Carlstedt-Duke J, Stierna P, Gustafsson J, Bronnegard M, et al. Evidence that the beta-isoform of the human glucocorticoid receptor does not act as a physiologically significant repressor. J Biol Chem 1997;272:26659-64.

66. Brogan IJ, Murray IA, Cerillo G, Needham M, White A, et al. Interaction of glucocorticoid receptor isoforms with transcription factors AP-1 and NF-kappaB: lack of effect of glucocorticoid receptor beta. Mol Cell Endocrinol 1999;157:95-104.

67. Kino T, Manoli I, Kelkar S, Wang Y, Su YA, et al. Glucocorticoid receptor (GR) beta has intrinsic, GRalpha-independent transcriptional activity. Biochem Biophys Res Commun 2009;381:671-5.

68. Lewis-Tuffin LJ, Cidlowski JA. The physiology of human glucocorticoid receptor beta (hGRbeta) and glucocorticoid resistance. Ann N Y Acad Sci 2006;1069:1-9.

69. Kino T, Su YA, Chrousos GP. Human glucocorticoid receptor isoform beta: recent understanding of its potential implications in physiology and pathophysiology. Cell Mol Life Sci 2009;66:3435-48.

70. Shahidi H, Vottero A, Stratakis CA, Taymans SE, Karl M, et al. Imbalanced expression of the glucocorticoid receptor isoforms in cultured lymphocytes from a patient with systemic glucocorticoid resistance and chronic lymphocytic leukemia. Biochem Biophys Res Commun 1999;254:559-65.

71. Koga Y, Matsuzaki A, Suminoe A, Hattori H, Kanemitsu S, et al. Differential mRNA expression of glucocorticoid receptor alpha and beta is associated with glucocorticoid sensitivity of acute lymphoblastic leukemia in children. Pediatr Blood Cancer 2005;45:121-7.

72. Rivers C, Levy A, Hancock J, Lightman S, Norman M. Insertion of an amino acid in the DNA-binding domain of the glucocorticoid receptor as a result of alternative splicing. J Clin Endocrinol Metab 1999;84:4283-6.

73. Beger C, Gerdes K, Lauten M, Tissing WJ, Fernandez-Munoz I, et al. Expression and structural analysis of glucocorticoid receptor isoform gamma in human leukaemia cells using an isoform-specific real-time polymerase chain reaction approach. Br J Haematol 2003;122:245-52.

74. Bedewy AM, El-Maghraby SM, Kandil NS, El-Bendary WR. The prognostic value of glucocorticoid receptors for adult acute lymphoblastic leukemia. Blood Res 2015;50:235-41.

75. Lauten M, Fernandez-Munoz I, Gerdes K, von Neuhoff N, Welte K, et al. Kinetics of the in vivo expression of glucocorticoid receptor splice variants during prednisone treatment in childhood acute lymphoblastic leukaemia. Pediatr Blood Cancer 2009;52:459-63.

76. Moalli PA, Pillay S, Krett NL, Rosen ST. Alternatively spliced glucocorticoid receptor messenger RNAs in glucocorticoid-resistant human multiple myeloma cells. Cancer Res 1993;53:3877-9.

77. de Lange P, Segeren CM, Koper JW, Wiemer E, Sonneveld P, et al. Expression in hematological malignancies of a glucocorticoid receptor splice variant that augments glucocorticoid receptor-mediated effects in transfected cells. Cancer Res 2001;61:3937-41.

78. Huang M, Inukai T, Kagami K, Abe M, Shinohara T, et al. Splicing variant profiles and single nucleotide polymorphisms of the glucocorticoid receptor gene in relation to glucocorticoid sensitivity of B-cell precursor acute lymphoblastic leukaemia. Hematol Oncol 2018;36:245-51.

79. Silva CM, Powell-Oliver FE, Jewell CM, Sar M, Allgood VE, et al. Regulation of the human glucocorticoid receptor by long-term and chronic treatment with glucocorticoid. Steroids 1994;59:436-42.

80. Schmidt S, Irving JA, Minto L, Matheson E, Nicholson L, et al. Glucocorticoid resistance in two key models of acute lymphoblastic leukemia occurs at the level of the glucocorticoid receptor. FASEB J 2006;20:2600-2.

81. Gruber G, Carlet M, Turtscher E, Meister B, Irving JA, et al. Levels of glucocorticoid receptor and its ligand determine sensitivity and kinetics of glucocorticoid-induced leukemia apoptosis. Leukemia 2009;23:820-3.

82. Govindan MV, Pothier F, Leclerc S, Palaniswami R, Xie B. Human glucocorticoid receptor gene promotor-homologous down regulation. J Steroid Biochem Mol Biol 1991;40:317-23.

83. Ramamoorthy S, Cidlowski JA. Ligand-induced repression of the glucocorticoid receptor gene is mediated by an NCoR1 repression complex formed by long-range chromatin interactions with intragenic glucocorticoid response elements. Mol Cell Biol 2013;33:1711-22.

84. Burnstein KL, Jewell CM, Cidlowski JA. Human glucocorticoid receptor cDNA contains sequences sufficient for receptor down- 
regulation. J Biol Chem 1990;265:7284-91.

85. Sanchez-Vega B, Gandhi V. Glucocorticoid resistance in a multiple myeloma cell line is regulated by a transcription elongation block in the glucocorticoid receptor gene (NR3C1). Br J Haematol 2009;144:856-64.

86. Hillmann AG, Ramdas J, Multanen K, Norman MR, Harmon JM. Glucocorticoid receptor gene mutations in leukemic cells acquired in vitro and in vivo. Cancer Res 2000;60:2056-62.

87. Mullighan CG, Goorha S, Radtke I, Miller CB, Coustan-Smith E, et al. Genome-wide analysis of genetic alterations in acute lymphoblastic leukaemia. Nature 2007;446:758-64.

88. Oshima K, Khiabanian H, da Silva-Almeida AC, Tzoneva G, Abate F, et al. Mutational landscape, clonal evolution patterns, and role of RAS mutations in relapsed acute lymphoblastic leukemia. Proc Natl Acad Sci U S A 2016;113:11306-11.

89. Grausenburger R, Bastelberger S, Eckert C, Kauer M, Stanulla M, et al. Genetic alterations in glucocorticoid signaling pathway components are associated with adverse prognosis in children with relapsed ETV6/RUNX1-positive acute lymphoblastic leukemia. Leuk Lymphoma 2016;57:1163-73.

90. Liang YN, Tang YL, Ke ZY, Chen YQ, Luo XQ, et al. MiR-124 contributes to glucocorticoid resistance in acute lymphoblastic leukemia by promoting proliferation, inhibiting apoptosis and targeting the glucocorticoid receptor. J Steroid Biochem Mol Biol 2017; 172:62-8.

91. Tessel MA, Benham AL, Krett NL, Rosen ST, Gunaratne PH. Role for microRNAs in regulating glucocorticoid response and resistance in multiple myeloma. Horm Cancer 2011;2:182-9.

92. Lv M, Zhang X, Jia H, Li D, Zhang B, et al. An oncogenic role of miR-142-3p in human T-cell acute lymphoblastic leukemia (T-ALL) by targeting glucocorticoid receptor-alpha and cAMP/PKA pathways. Leukemia 2012;26:769-77.

93. Wallace AD, Cidlowski JA. Proteasome-mediated glucocorticoid receptor degradation restricts transcriptional signaling by glucocorticoids. J Biol Chem 2001;276:42714-21.

94. Paugh SW, Bonten EJ, Savic D, Ramsey LB, Thierfelder WE, et al. NALP3 inflammasome upregulation and CASP1 cleavage of the glucocorticoid receptor cause glucocorticoid resistance in leukemia cells. Nat Genet 2015;47:607-14.

95. Lu NZ, Cidlowski JA. Translational regulatory mechanisms generate N-terminal glucocorticoid receptor isoforms with unique transcriptional target genes. Mol Cell 2005;18:331-42.

96. Yudt MR, Cidlowski JA. Molecular identification and characterization of a and b forms of the glucocorticoid receptor. Mol Endocrinol 2001;15:1093-103.

97. Lu NZ, Collins JB, Grissom SF, Cidlowski JA. Selective regulation of bone cell apoptosis by translational isoforms of the glucocorticoid receptor. Mol Cell Biol 2007;27:7143-60.

98. Wu I, Shin SC, Cao Y, Bender IK, Jafari N, et al. Selective glucocorticoid receptor translational isoforms reveal glucocorticoidinduced apoptotic transcriptomes. Cell Death Dis 2013;4:e453.

99. Elmore S. Apoptosis: a review of programmed cell death. Toxicol Pathol 2007;35:495-516.

100. Kale J, Osterlund EJ, Andrews DW. BCL-2 family proteins: changing partners in the dance towards death. Cell Death Differ 2018;25:65-80.

101. Shamas-Din A, Brahmbhatt H, Leber B, Andrews DW. BH3-only proteins: Orchestrators of apoptosis. Biochim Biophys Acta 2011;1813:508-20.

102. Rosenthal A, Younes A. High grade B-cell lymphoma with rearrangements of MYC and BCL2 and/or BCL6: double hit and triple hit lymphomas and double expressing lymphoma. Blood Rev 2017;31:37-42.

103. Wang Z, Malone MH, He H, McColl KS, Distelhorst CW. Microarray analysis uncovers the induction of the proapoptotic BH3-only protein Bim in multiple models of glucocorticoid-induced apoptosis. J Biol Chem 2003;278:23861-7.

104. Puthalakath H, Strasser A. Keeping killers on a tight leash: transcriptional and post-translational control of the pro-apoptotic activity of BH3-only proteins. Cell Death Differ 2002;9:505-12.

105. Jiang N, Koh GS, Lim JY, Kham SK, Ariffin H, et al. BIM is a prognostic biomarker for early prednisolone response in pediatric acute lymphoblastic leukemia. Exp Hematol 2011;39:321-9, 9 e1-3.

106. Zhao YN, Guo X, Ma ZG, Gu L, Ge J, et al. Pro-apoptotic protein BIM in apoptosis of glucocorticoid-sensitive and -resistant acute lymphoblastic leukemia CEM cells. Med Oncol 2011;28:1609-17.

107. Bachmann PS, Gorman R, Papa RA, Bardell JE, Ford J, et al. Divergent mechanisms of glucocorticoid resistance in experimental models of pediatric acute lymphoblastic leukemia. Cancer Res 2007;67:4482-90.

108. Lu J, Quearry B, Harada H. p38-MAP kinase activation followed by BIM induction is essential for glucocorticoid-induced apoptosis in lymphoblastic leukemia cells. FEBS Lett 2006;580:3539-44.

109. Bachmann PS, Gorman R, Mackenzie KL, Lutze-Mann L, Lock RB. Dexamethasone resistance in B-cell precursor childhood acute lymphoblastic leukemia occurs downstream of ligand-induced nuclear translocation of the glucocorticoid receptor. Blood 2005;105:2519-26.

110. Abrams MT, Robertson NM, Yoon K, Wickstrom E. Inhibition of glucocorticoid-induced apoptosis by targeting the major splice variants of BIM mRNA with small interfering RNA and short hairpin RNA. J Biol Chem 2004;279:55809-17.

111. Melarangi T, Zhuang J, Lin K, Rockliffe N, Bosanquet AG, et al. Glucocorticoid resistance in chronic lymphocytic leukaemia is associated with a failure of upregulated Bim/Bcl-2 complexes to activate Bax and Bak. Cell Death Dis 2012;3:e372.

112. Iglesias-Serret D, de Frias M, Santidrian AF, Coll-Mulet L, Cosialls AM, et al. Regulation of the proapoptotic BH3-only protein BIM by glucocorticoids, survival signals and proteasome in chronic lymphocytic leukemia cells. Leukemia 2007;21:281-7.

113. Follin-Arbelet V, Misund K, Naderi EH, Ugland H, Sundan A, et al. The natural compound forskolin synergizes with dexamethasone 
to induce cell death in myeloma cells via BIM. Sci Rep 2015;5:13001.

114. Dong H, Carlton ME, Lerner A, Epstein PM. Effect of cAMP signaling on expression of glucocorticoid receptor, Bim and Bad in glucocorticoid-sensitive and resistant leukemic and multiple myeloma cells. Front Pharmacol 2015;6:230.

115. Kervoelen C, Menoret E, Gomez-Bougie P, Bataille R, Godon C, et al. Dexamethasone-induced cell death is restricted to specific molecular subgroups of multiple myeloma. Oncotarget 2015;6:26922-34.

116. Lopez-Royuela N, Balsas P, Galan-Malo P, Anel A, Marzo I, et al. Bim is the key mediator of glucocorticoid-induced apoptosis and of its potentiation by rapamycin in human myeloma cells. Biochim Biophys Acta 2010;1803:311-22.

117. Gilley J, Coffer PJ, Ham J. FOXO transcription factors directly activate bim gene expression and promote apoptosis in sympathetic neurons. J Cell Biol 2003;162:613-22.

118. Dijkers PF, Medema RH, Lammers JW, Koenderman L, Coffer PJ. Expression of the pro-apoptotic Bcl-2 family member Bim is regulated by the forkhead transcription factor FKHR-L1. Curr Biol 2000;10:1201-4.

119. Xie M, Yang A, Ma J, Wu M, Xu H, et al. Akt2 mediates glucocorticoid resistance in lymphoid malignancies through FoxO3a/Bim axis and serves as a direct target for resistance reversal. Cell Death Dis 2019;9:1013.

120. Bachmann PS, Piazza RG, Janes ME, Wong NC, Davies C, et al. Epigenetic silencing of BIM in glucocorticoid poor-responsive pediatric acute lymphoblastic leukemia, and its reversal by histone deacetylase inhibition. Blood 2010;116:3013-22.

121. Jing D, Bhadri VA, Beck D, Thoms JA, Yakob NA, et al. Opposing regulation of BIM and BCL2 controls glucocorticoid-induced apoptosis of pediatric acute lymphoblastic leukemia cells. Blood 2015;125:273-83.

122. Holleman A, Cheok MH, den Boer ML, Yang W, Veerman AJ, et al. Gene-expression patterns in drug-resistant acute lymphoblastic leukemia cells and response to treatment. N Engl J Med 2004;351:533-42.

123. Wei G, Twomey D, Lamb J, Schlis K, Agarwal J, et al. Gene expression-based chemical genomics identifies rapamycin as a modulator of MCL1 and glucocorticoid resistance. Cancer Cell 2006;10:331-42.

124. Aries IM, Hansen BR, Koch T, van den Dungen R, Evans WE, et al. The synergism of MCL1 and glycolysis on pediatric acute lymphoblastic leukemia cell survival and prednisolone resistance. Haematologica 2013;98:1905-11.

125. Bonapace L, Bornhauser BC, Schmitz M, Cario G, Ziegler U, et al. Induction of autophagy-dependent necroptosis is required for childhood acute lymphoblastic leukemia cells to overcome glucocorticoid resistance. J Clin Invest 2010;120:1310-23.

126. Lynch JT, Rajendran R, Xenaki G, Berrou I, Demonacos C, et al. The role of glucocorticoid receptor phosphorylation in Mcl-1 and NOXA gene expression. Mol Cancer 2010;9:38.

127. Paulus A, Chitta K, Akhtar S, Personett D, Miller KC, et al. AT-101 downregulates BCL2 and MCL1 and potentiates the cytotoxic effects of lenalidomide and dexamethasone in preclinical models of multiple myeloma and Waldenstrom macroglobulinaemia. Br J Haematol 2014;164:352-65.

128. Aries IM, Bodaar K, Karim SA, Chonghaile TN, Hinze L, et al. PRC2 loss induces chemoresistance by repressing apoptosis in T cell acute lymphoblastic leukemia. J Exp Med 2018;215:3094-114.

129. Matassa DS, Amoroso MR, Maddalena F, Landriscina M, Esposito F. New insights into TRAP1 pathway. Am J Cancer Res 2012;2:235-48.

130. Aries IM, Jerchel IS, van den Dungen RE, van den Berk LC, Boer JM, et al. EMP1, a novel poor prognostic factor in pediatric leukemia regulates prednisolone resistance, cell proliferation, migration and adhesion. Leukemia 2014;28:1828-37.

131. Robak P, Drozdz I, Szemraj J, Robak T. Drug resistance in multiple myeloma. Cancer Treat Rev 2018;70:199-208.

132. Paakinaho V, Kaikkonen S, Makkonen H, Benes V, Palvimo JJ. SUMOylation regulates the chromatin occupancy and antiproliferative gene programs of glucocorticoid receptor. Nucleic Acids Res 2014;42:1575-92.

133. Galliher-Beckley AJ, Cidlowski JA. Emerging roles of glucocorticoid receptor phosphorylation in modulating glucocorticoid hormone action in health and disease. IUBMB Life 2009;61:979-86.

134. Kino T. GR-regulating Serine/Threonine kinases: new physiologic and pathologic implications. Trends Endocrinol Metab 2018;29:260-70.

135. Cargnello M, Roux PP. Activation and function of the MAPKs and their substrates, the MAPK-activated protein kinases. Microbiol Mol Biol Rev 2011;75:50-83.

136. Miller AL, Webb MS, Copik AJ, Wang Y, Johnson BH, et al. p38 Mitogen-activated protein kinase (MAPK) is a key mediator in glucocorticoid-induced apoptosis of lymphoid cells: correlation between p38 MAPK activation and site-specific phosphorylation of the human glucocorticoid receptor at serine 211. Mol Endocrinol 2005;19:1569-83.

137. Itoh M, Adachi M, Yasui H, Takekawa M, Tanaka H, et al. Nuclear export of glucocorticoid receptor is enhanced by c-Jun N-terminal kinase-mediated phosphorylation. Mol Endocrinol 2002;16:2382-92.

138. Rogatsky I, Logan SK, Garabedian MJ. Antagonism of glucocorticoid receptor transcriptional activation by the c-Jun N-terminal kinase. Proc Natl Acad Sci U S A 1998;95:2050-5.

139. Galliher-Beckley AJ, Williams JG, Cidlowski JA. Ligand-independent phosphorylation of the glucocorticoid receptor integrates cellular stress pathways with nuclear receptor signaling. Mol Cell Biol 2011;31:4663-75.

140. Jones CL, Gearheart CM, Fosmire S, Delgado-Martin C, Evensen NA, et al. MAPK signaling cascades mediate distinct glucocorticoid resistance mechanisms in pediatric leukemia. Blood 2015;126:2202-12.

141. Takabe S, Mochizuki K, Goda T. De-phosphorylation of GR at Ser203 in nuclei associates with GR nuclear translocation and GLUT5 gene expression in Caco-2 cells. Arch Biochem Biophys 2008;475:1-6.

142. Krstic MD, Rogatsky I, Yamamoto KR, Garabedian MJ. Mitogen-activated and cyclin-dependent protein kinases selectively and differentially modulate transcriptional enhancement by the glucocorticoid receptor. Mol Cell Biol 1997;17:3947-54.

143. Kino T, Ichijo T, Amin ND, Kesavapany S, Wang Y, et al. Cyclin-dependent kinase 5 differentially regulates the transcriptional 
activity of the glucocorticoid receptor through phosphorylation: clinical implications for the nervous system response to glucocorticoids and stress. Mol Endocrinol 2007;21:1552-68.

144. Blind RD, Garabedian MJ. Differential recruitment of glucocorticoid receptor phospho-isoforms to glucocorticoid-induced genes. J Steroid Biochem Mol Biol 2008;109:150-7.

145. Chen W, Dang T, Blind RD, Wang Z, Cavasotto CN, et al. Glucocorticoid receptor phosphorylation differentially affects target gene expression. Mol Endocrinol 2008;22:1754-66.

146. Miller AL, Garza AS, Johnson BH, Thompson EB. Pathway interactions between MAPKs, mTOR, PKA, and the glucocorticoid receptor in lymphoid cells. Cancer Cell Int 2007;7:3.

147. Shi Y, Wang G, Muhowski EM, McCaw L, Wang C, et al. Ibrutinib reprograms the glucocorticoid receptor in chronic lymphocytic leukemia cells. Leukemia 2019; doi: 10.1038/s41375-019-0381-4.

148. Polak R, Buitenhuis M. The PI3K/PKB signaling module as key regulator of hematopoiesis: implications for therapeutic strategies in leukemia. Blood 2012;119:911-23.

149. Curran E, Smith SM. Phosphoinositide 3-kinase inhibitors in lymphoma. Curr Opin Oncol 2014;26:469-75.

150. Evangelisti C, Cappellini A, Oliveira M, Fragoso R, Barata JT, et al. Phosphatidylinositol 3-kinase inhibition potentiates glucocorticoid response in B-cell acute lymphoblastic leukemia. J Cell Physiol 2018;233:1796-811.

151. Spijkers-Hagelstein JA, Pinhancos SS, Schneider P, Pieters R, Stam RW. Chemical genomic screening identifies LY294002 as a modulator of glucocorticoid resistance in MLL-rearranged infant ALL. Leukemia 2014;28:761-9.

152. Piovan E, Yu J, Tosello V, Herranz D, Ambesi-Impiombato A, et al. Direct reversal of glucocorticoid resistance by AKT inhibition in acute lymphoblastic leukemia. Cancer cell 2013;24:766-76.

153. Habib T, Sadoun A, Nader N, Suzuki S, Liu W, et al. AKT1 has dual actions on the glucocorticoid receptor by cooperating with 14-33. Molecular and cellular endocrinology 2017;439:431-43.

154. Lesovaya E, Agarwal S, Readhead B, Vinokour E, Baida G, et al. Rapamycin modulates glucocorticoid receptor function, blocks atrophogene REDD1, and protects skin from steroid atrophy. J Invest Dermatol 2018;138:1935-44.

155. Agarwal S, Mirzoeva S, Readhead B, Dudley JT, Budunova I. PI3K inhibitors protect against glucocorticoid-induced skin atrophy. EBioMedicine 2019;41:526-37.

156. Serafin V, Capuzzo G, Milani G, Minuzzo SA, Pinazza M, et al. Glucocorticoid resistance is reverted by LCK inhibition in pediatric T-cell acute lymphoblastic leukemia. Blood 2017;130:2750-61.

157. Galliher-Beckley AJ, Williams JG, Collins JB, Cidlowski JA. Glycogen synthase kinase 3beta-mediated serine phosphorylation of the human glucocorticoid receptor redirects gene expression profiles. Mol Cell Biol 2008;28:7309-22.

158. Maurer U, Charvet C, Wagman AS, Dejardin E, Green DR. Glycogen synthase kinase-3 regulates mitochondrial outer membrane permeabilization and apoptosis by destabilization of MCL-1. Mol Cell 2006;21:749-60.

159. Spokoini R, Kfir-Erenfeld S, Yefenof E, Sionov RV. Glycogen synthase kinase-3 plays a central role in mediating glucocorticoidinduced apoptosis. Mol Endocrinol 2010;24:1136-50.

160. Delgado-Martin C, Meyer LK, Huang BJ, Shimano KA, Zinter MS, et al. JAK/STAT pathway inhibition overcomes IL7-induced glucocorticoid resistance in a subset of human T-cell acute lymphoblastic leukemias. Leukemia 2017;31:2568-76.

161. Beesley AH, Firth MJ, Ford J, Weller RE, Freitas JR, et al. Glucocorticoid resistance in T-lineage acute lymphoblastic leukaemia is associated with a proliferative metabolism. Br J Cancer 2009;100:1926-36.

162. Samuels AL, Heng JY, Beesley AH, Kees UR. Bioenergetic modulation overcomes glucocorticoid resistance in T-lineage acute lymphoblastic leukaemia. Br J Haematol 2014;165:57-66.

163. Chan LN, Chen Z, Braas D, Lee JW, Xiao G, et al. Metabolic gatekeeper function of B-lymphoid transcription factors. Nature 2017;542:479-83.

164. Kruth KA, Fang M, Shelton DN, Abu-Halawa O, Mahling R, et al. Suppression of B-cell development genes is key to glucocorticoid efficacy in treatment of acute lymphoblastic leukemia. Blood 2017;129:3000-8.

165. Real PJ, Tosello V, Palomero T, Castillo M, Hernando E, et al. Gamma-secretase inhibitors reverse glucocorticoid resistance in T cell acute lymphoblastic leukemia. Nat Med 2009;15:50-8.

166. Sionov RV, Kfir-Erenfeld S, Spokoini R, Yefenof E. A role for bcl-2 in notch1-dependent transcription in thymic lymphoma cells. Adv Hematol 2012;2012:435241.

167. Revollo JR, Oakley RH, Lu NZ, Kadmiel M, Gandhavadi M, et al. HES1 is a master regulator of glucocorticoid receptor-dependent gene expression. Sci Signal 2013;6:ra103.

168. Ratman D, Vanden Berghe W, Dejager L, Libert C, Tavernier J, et al. How glucocorticoid receptors modulate the activity of other transcription factors: a scope beyond tethering. Mol Cell Endocrinol 2013;380:41-54.

169. Lonard DM, O'Malley B W. Nuclear receptor coregulators: judges, juries, and executioners of cellular regulation. Mol Cell 2007;27:691-700.

170. King HA, Trotter KW, Archer TK. Chromatin remodeling during glucocorticoid receptor regulated transactivation. Biochim Biophys Acta 2012;1819:716-26.

171. Pottier N, Yang W, Assem M, Panetta JC, Pei D, et al. The SWI/SNF chromatin-remodeling complex and glucocorticoid resistance in acute lymphoblastic leukemia. J Natl Cancer Inst 2008;100:1792-803.

172. Hittelman AB, Burakov D, Iniguez-Lluhi JA, Freedman LP, Garabedian MJ. Differential regulation of glucocorticoid receptor transcriptional activation via AF-1-associated proteins. EMBO J 1999;18:5380-8.

173. Chen W, Rogatsky I, Garabedian MJ. MED14 and MED1 differentially regulate target-specific gene activation by the glucocorticoid 
receptor. Mol Endocrinol 2006;20:560-72.

174. Rao NA, McCalman MT, Moulos P, Francoijs KJ, Chatziioannou A, et al. Coactivation of GR and NFKB alters the repertoire of their binding sites and target genes. Genome Res 2011;21:1404-16.

175. Oh KS, Patel H, Gottschalk RA, Lee WS, Baek S, et al. Anti-inflammatory chromatinscape suggests alternative mechanisms of glucocorticoid receptor action. Immunity 2017;47:298-309.e5.

176. Uhlenhaut NH, Barish GD, Yu RT, Downes M, Karunasiri M, et al. Insights into negative regulation by the glucocorticoid receptor from genome-wide profiling of inflammatory cistromes. Mol Cell 2013;49:158-71.

177. Reily MM, Pantoja C, Hu X, Chinenov Y, Rogatsky I. The GRIP1:IRF3 interaction as a target for glucocorticoid receptor-mediated immunosuppression. EMBO J 2006;25:108-17.

178. Bittencourt D, Wu DY, Jeong KW, Gerke DS, Herviou L, et al. G9a functions as a molecular scaffold for assembly of transcriptional coactivators on a subset of glucocorticoid receptor target genes. Proc Natl Acad Sci U S A 2012;109:19673-8.

179. Marke R, Havinga J, Cloos J, Demkes M, Poelmans G, et al. Tumor suppressor IKZF1 mediates glucocorticoid resistance in B-cell precursor acute lymphoblastic leukemia. Leukemia 2016;30:1599-603.

180. Kuiper RP, Waanders E, van der Velden VH, van Reijmersdal SV, Venkatachalam R, et al. IKZF1 deletions predict relapse in uniformly treated pediatric precursor B-ALL. Leukemia 2010;24:1258-64.

181. Mullighan CG, Su X, Zhang J, Radtke I, Phillips LA, et al. Deletion of IKZF1 and prognosis in acute lymphoblastic leukemia. N Engl J Med 2009;360:470-80.

182. Scheijen B, Boer JM, Marke R, Tijchon E, van Ingen Schenau D, et al. Tumor suppressors BTG1 and IKZF1 cooperate during mouse leukemia development and increase relapse risk in B-cell precursor acute lymphoblastic leukemia patients. Haematologica 2017;102:541-51.

183. van Galen JC, Kuiper RP, van Emst L, Levers M, Tijchon E, et al. BTG1 regulates glucocorticoid receptor autoinduction in acute lymphoblastic leukemia. Blood 2010;115:4810-9.

184. Jones CL, Bhatla T, Blum R, Wang J, Paugh SW, et al. Loss of TBL1XR1 disrupts glucocorticoid receptor recruitment to chromatin and results in glucocorticoid resistance in a B-lymphoblastic leukemia model. J Biol Chem 2014;289:20502-15.

185. Perissi V, Aggarwal A, Glass CK, Rose DW, Rosenfeld MG. A corepressor/coactivator exchange complex required for transcriptional activation by nuclear receptors and other regulated transcription factors. Cell 2004;116:511-26.

186. Perissi V, Scafoglio C, Zhang J, Ohgi KA, Rose DW, et al. TBL1 and TBLR1 phosphorylation on regulated gene promoters overcomes dual CtBP and NCoR/SMRT transcriptional repression checkpoints. Mol Cell 2008;29:755-66.

187. Mullighan CG, Zhang J, Kasper LH, Lerach S, Payne-Turner D, et al. CREBBP mutations in relapsed acute lymphoblastic leukaemia. Nature 2011;471:235-9.

188. John S, Sabo PJ, Thurman RE, Sung MH, Biddie SC, et al. Chromatin accessibility pre-determines glucocorticoid receptor binding patterns. Nat Genet 2011;43:264-8.

189. Love MI, Huska MR, Jurk M, Schopflin R, Starick SR, et al. Role of the chromatin landscape and sequence in determining cell typespecific genomic glucocorticoid receptor binding and gene regulation. Nucleic Acids Res 2017;45:1805-19.

190. Jing D, Huang Y, Liu X, Sia KCS, Zhang JC, et al. Lymphocyte-specific chromatin accessibility pre-determines glucocorticoid resistance in acute lymphoblastic leukemia. Cancer Cell 2018;34:906-21.e8. 